\title{
Ali Shari'ati's revolutionary Islamic thought and its relevance to the contemporary socio-political transformation
}

\author{
Anjar Nugroho \\ Universitas Muhammadiyah Purwokerto \\ E-mail:anjar@ump.ac.id
}

Tulus Warsito, Surwandono

Universitas Muhammadiyah Yogyakarta

DOI: $10.18326 /$ ijims.v7i2.251-276

\begin{abstract}
s
Ali Shari'ati emerged as an enlightened intellectual figure in the phenomenon of the authoritarian and oppressive power of the Syah Pahlavi regime. Shari'ati appeared as a pioneer of radical ideas about Islam and the revolution which stemmed from the Shi'a teachings that had been grafted into the revolutionary tradition of the Third World and Marxism. Shari'ati succeeded in establishing a revolutionary Islamic ideology that became the basis of the mass collective consciousness against the regime of the Syah. In Shari'ati's thought, Islam is an emancipatory ideology and liberation. The progressive and revolutionary view of Shari'ati's Islam derives from a belief system of tauhid. While tauhid in Shari'ati's view is the unity among God, man and the universe, the society which is full of social discrimination, injustice, and arbitrariness can be categorized as Shirk, the opponent of tauhid. In the context of the Iranian revolution, the Shari'ati's Islamic thought and ideology became the fourth
\end{abstract}


bridge or road from the ideological stalemate of the pre-revolutionary opposition movement, which is between secularist-nationalist, Marxist-Communist and Islamic Fundamentalism. Further, Shari'ati's ideology paved the way for the acceptance of Imam Khomeini as a revolutionary leader. This paper aims to contextualize Ali Shari'ti's views on socio-political change in Indonesia.

Ali Shari'ati muncul menjadi sosok intelektual tercerahkan dalam fenomena kekuasaan rezim Syah Pahlevi yang otoriter dan menindas. Shari'ati lalu tampil sebagai pelopor gagasan-gagasan radikal tentang Islam dan revolusi yang bersumber dari ajaran Syi'ah yang sudah dicangkokkan dengan tradisi revolusioner Dunia Ketiga dan Marxisme. Ali Shari' ati berhasil membangun ideologi Islam revolusioner yang kemudian menjadi basis kesadaran kolektif massa menentang kekuasaan rezim Syah. Dalam pemikiran Shari'ati, Islam adalah sebuah ideologi emansipasi dan pembebasan. Pandangan Islam Ali Shari'ati yang progresif dan revolusioner bersumber pada satu sistem keyakinan yaitu tauhid. Jika tauhid dalam pandangan Shari'ati adalah kesatuan antara Tuhan, manusia dan alam semesta, maka kondisi masyarakat yang penuh diskriminasi sosial, ketidakadilan, dan kesewenang-wenangan dapat dikategorikan sebagai syirk, lawan dari tauhid. Dalam konteks revolusi Iran, tawaran pemikiran dan ideologi Islam Syari'ati menjadi jembatan atau jalan keempat dari kebuntuan ideologi gerakan oposisi pra-revolusi, yaitu antara nasionalis-sekuler, Marxis-Komunis dan Fundamentalisme Islam. Ideologi Shari'ati melapangkan jalan bagi diterimanya Imam Khomeini sebagai pemimpin revolusioner. Tulisan ini hendak mengkontekstualisasikan pemikiran Ali Shari'ati dalam perubahan sosialpolitik di Indonesia.

Keywords: Islam; Revolution; Social-Transformation; Political Islam

\section{Introduction}

Many researchers claim that Shari'ati played an important role in the Islamic Revolution of Iran. Although he died a year before the revolution took place, his thoughts influenced many figures of the 1978-1979 revolutionary movement. L. Carl Brown ${ }^{1}$ states that Imam Khomeini

\footnotetext{
${ }^{1}$ Carl L. Brown, Religion and State: The Muslim Approach to Politics, New York: Columbia University Press, 2000, 168-169.
} 
was one of the most important figures in the revolution that was slightly influenced by Shari'ati's revolutionary thinking.

Brown's argument is common as many figures expressed a similar opinion. At least, Shari'ati was placed in the position of a revolutionary ideologue that could eventually arouse the resistance of the Iranian people against the Syah's regime. Hamid Dabashi claims that the "par-excellence ideologist" was in the Iranian revolution, Shari'ati². Furthermore, H.E. Chehabi states that "undeniably, after Khomeini, Shari'ati was the most influential figure in the Islamic movement that led to the 1979 revolution" ${ }^{3}$. Abdulaziz Sachedina asserts that Shari'ati and his revolutionary thoughts have contributed to the actual revolution of 1978-1979.

Shari'ati had a distinct Islamic idea of revolutionary Islamic thought, which was different from the mainstream Islamic thought. This so-called multi-party segment of thought was an important factor arousing the thinking of young Iranians with Islamic orientation to rise up against the Syah's regime. Shari'ati's thought represented a group of non- ulamas intellectuals, characterized by the idea of criticism based on a Western revolutionary ideology that had been grafted into Shi'a's theology. In this case, he was together with his companions, such as Mehdi Bazargan and Bani Sadr. In the other group, there were traditional ulamas whose

${ }^{2}$ Hamid Dabashi, "Ali Shari'ati: The Islamic Ideologue Par Excellence", in Hamid Dabashi, Theology of Discontent: The Ideological Foundation of The Islamic Revolution in Iran, New York: New York University Press, 1993, 102. See also Ali Rahnema, "An Islamic Utopian: a Political Biography of Ali Shari'ati”, Middle East Journal, Vol. 54, No. 1 (Winter, 2000), 139-140.

${ }^{3}$ H.E. Chehabi, Iranian Politics and Religious Modernism, New York: Cornell University Press, 1986, 355.

${ }^{4}$ Abdulaziz A. Sachedina, "Ali Shari'ati: Ideologue of the Iranian Revolution", in John L. Esposito (ed.), Voices of Resurgent Islam, New York, Oxford: Oxford University Press, 1983, 211. See Also Naghi Yousef, "Religion and Revolution in the Modern World: Ali Shari'ati's Islam and Parsian Revolution”, Social and Economic Studies, Vol. 44, No. 2/3 (June/September, 1995), 402-407. 
criticism of the Syah's regime was based on the foundation of pure Shiite theology, namely the return of "the mysterious Imam". Some names appearing in this group were Ayatullah Murtada Mutahhari and Ayatullah Ruhullah Khomeini.

This paper aims to explore Shari'ati's revolutionary Islamic thought and the relationship between the thought and the contemporary sociopolitical change, especially in Indonesia. Reflecting on Shari'ati's thought in Indonesia's political condition is not easy considering the different ideological backgrounds of Shari'ati and the majority of people in Indonesia as well as the wide time span between the time of Shari'ati's thought and the time of Indonesian's perspective. This certainly provides different background conditions and problems.

\section{Construction of Shari'ati's thought}

\section{Islam: the religion of liberation}

The understanding of Islam offered by Shari'ati was different from the mainstream's understanding at the time. Islam understood by many in Shari'ati's time was Islam with its simple ritual and figh that did not touch upon social and political issues. Islam was just a collection of dogmas to govern the way individuals worship God; it did not provide the most effective way to uphold justice, a strategy against tyranny, or guidance to defend the oppressed (mustad'afin). Such an Islam greatly benefits the ruling authorities and induces injustice on many occasions, for it can take refuge behind the dogmas that have been made in such a way as to protect their interests.

\footnotetext{
${ }^{5}$ See Ali Shari' ati, What Is To Be Done: The Enlightened and Thinkers and Islamic Renaisance, Houston: IRIS, 1986, 1-2. Compare with William Cosgrave, "The Theology of Liberation", The Furrow, Vol. 37, No. 8 (August, 2007), 505-516.
} 
In the context of the political situation in the era of Shari'ati, this mainstream Islamic discourse was used by most scholars to support the regime's power. When the Syah's regime oppressed its people, these regimes ulamas were incapable of doing anything for the benefit of the people. Instead, the ulamas were forced to continually provide religious justification for the Syah's policies. Shari'ati viewed such Islam as a rulerstyle Muslim (the Islamic way of Uthman, the third Khalifa of Islam). On the other hand, authentic Islam, as Shari'ati states, is the Islam of Abu Dzar, the Prophet's companion of social thought.

Abu Dhar was watching these shameful scenes and because he could no longer bear it, could no longer remain silent, he rebelled, a manly and wonderful rebellion; an uprising which caused rebellion in all the Islamic lands against 'Uthman; an uprising from which the waves of enthusiasm can still be felt until the present day in the situations of human societies. Abu Dhar was trying to develop the economic and political unity of Islam and the regime of 'Uthman was reviving aristocracy. Abu Dhar believed Islam to be the refuge of the helpless, the oppressed and the humiliated people and 'Uthman, the tool of capitalism, was the bastion to preserve the interests of the usurers, the wealthy and the aristocrats. ${ }^{6}$

According to Shari'ati, liberation Islam is Islam inherited by Imam Husayn; His martyrdom at Karbala was a source of inspiration for the oppressed to preserve the authentic Islam. Thus, such Islam is the earliest Shi'a Islam. The revolutionary Shi'a Islam was personified by Abu Dharr al-Ghifari with his hermit and Imam Hussein with his martyrdom. Both are symbols of the eternal struggle of the oppression against unjust rulers. This revolutionary Shi'a Islam then experienced a "taming" in the hands of the upper classes - political rulers and ulama who

${ }^{6}$ Ali Shari'ati, "And Once Again Abu-Dhar", http://www.iranchamber.com/personalities/ashariati/works/once_again_abu_dhar7.php, 
gave legitimacy to "Islam" in the ruler version?.

For Shari'ati, the true Islam is revolutionary, and true Shi'a is revolutionary Islam ${ }^{8}$. However, in the course of time, Islam has turned into a trap of prayers and rituals that are completely meaningless in life. Islam is only a religion that deals with how people die, but it does not deal with the aspects of how people can survive in life in the midst of discrimination, exploitation, and oppression of unjust rulers.

Unfortunately, as Shari'ati had been disquieted, this revolutionary Islam soon became hard to status quo. Islam is laden with feudalism and the ulama are supporting the accustomed establishment. They wrote more books on ritual rules and spent their time to discuss furu'iyah matters in shari'a, and completely undermine the meaning of Islamic elan vital by creating active social justice and Islamic awareness of weak and oppressed groups (Mustad'afin). They identify themselves as mustakbirin (strong and arrogant people).

Shari'ati's major contribution to the society change is their ability to reconstruct the idea of revolution based on local culture. Shari'ati used Red Shi' ite language as a symbol that the idea of the revolution did not come solely from Western theory, but the idea of revolution existed in the Shi'a tradition run by the Iranians. Shari'ati used the term Red Shi'a to distinguish Shi'a from rituals without taking the wisdom behind the ritual. Ali Shari'ati criticized the Shi'a scholars who commemorated the tragedy of Karbala as an annual event without interpreting the basic spirit of the event. Shari'ati perceived the event of Karbala as a symbol of persistence of the leader of the people against the truth.

\footnotetext{
${ }^{7}$ Azyumardi Azra, Pergolakan Politik Islam: Dari Fundamentalisme, Modernisme, Hingga Post-Modernisme, Jakarta: Paramadina, 1996, 77-78.

${ }^{8}$ Robert D. Lee, "Ali Shari'ati”, in Mencari Islam Autentik: Dari Nalar Puitis Iqbal, Hingga Nalar Kritis Arkoun, trans. Ahmad Baiquni, Bandung: Mizan, 2000, 140.
} 


\section{Tauhid: the foundation of liberative Islam}

The progressive and revolutionary view of Shari'ati stems from a belief system of tauhid. In Shari'ati's hands, the traditional technical term was transformed into a radical and Jacobin-impressed, socialist, idealist, and trans historical. He establishes tauhid as a sword to combat religious divisions, knowledge sharing, separation of God from humans, and the erroneous historical events. ${ }^{9}$

Tauhid in this case is a mystical-philosophical world view of the universe as a living organism without dichotomy, all unity in the trinity between three hypotheses: God, men, and the nature. For Shari'ati, tauhid reflects that the nature is a totality of harmony creations. The responsibility of Muslims is to recognize and accept the rumination and to mobilize it massively:

My world-view consist of tauhid. Tauhid in the sense of oneness of God is of course accepted by all monotheist. But tauhid as a worldview in the sense I intend in my theory means about the whole universe as a unity. ${ }^{10}$

Tauhid is not only the oneness of God, but also the unity of mankind. The concept of unity of liberation is very close to the concept of universal humanity that aspires to justice and virtue. The true concept of tauhid is to create a structure which is free of exploitation and elevate basic human rights. Submission to God does not mean eliminating to do good deeds and prevent evil. The meaning of submission to God is historical activism. This means humans have an obligation to show their existence as a creature with reason and conscience. ${ }^{11}$

Tauhid views the world as an empire. On the other hand, Shirk views the world as a feudal system. With this view, then the world has the will,

\footnotetext{
${ }_{9}^{9}$ Robert D. Lee, “Ali Shari'ati”..., 150.

${ }^{10}$ Ali Shari'ati, On the Sosiology of Islam, Berkeley: Mizan Press, 1979, 82.

${ }^{11}$ Nurcholish Madjid, Islam Doktrin dan Peradaban, Sebuah Telaah Kritis Tentang Masalah Keimanan, Kemanusiaan, dan Kemodernan, Jakarta: Paramadina, 2000, 110.
} 
self-awareness, responsiveness, and goals. Relying on this belief, Shari'ati rejected polytheism, dualism, and trinitarians. He only believed in tauhid, monotheism. Monotheism rejects all confessions and human beliefs over false Gods. While in the days of Jahiliyyah, the false Gods were manifested in the form of idols, in this modern age, according to Shari'ati, false Gods are manifested in many aspects and fields that are wider and more complex than just idolatry worships. The Gods are more a tyrannical system full of oppression, or the glory of the world that when it comes to seizing, it must seize the rights of others. ${ }^{12}$

After tauhid has been standardized into a world-view, Shari'ati reinforces its revolutionary idea by demonstrating the need for the totality of engagement, outpouring, and any potential to accumulate the power of society. For that purpose, Shari'ati refers to one of the most basic and fundamental doctrines of Islam - moreover in the Shiite tradition of Iran - the martyrdom doctrine (shahadah). The doctrine of shahid refers to the death of Husein in the field of Karbala by the armies of Yazid, the ruling regime at the time. With this doctrine, Shari'ati invited the whole Iranian society to give themselves to the totality of the ultimate sacrifice of dying in the way of God. For Shari'ati, the shahid is the heart of history that always demands the faithful to be ready to sacrifice both with their soul and body, willing to die for a victorious purpose.

The theological conception of tauhid is actually a conception of noble principles or values that preserve human life on this earth: truth, compassion, sincerity, kindness, equality, and human fraternity. Muhammad, the messenger, devotes his life to declare the truth and establishing a social order based on these noble principles and values. The Prophet fought against these forces, the forces that divide humanity into rival factions, classes and groups, where one class oppresses another. They

\footnotetext{
${ }^{12}$ Ali Shari'ati, "Hajj", http://www.shariati.com//hajj.
} 
struggle against class discrimination, injustice, tyranny, and oppression. The Prophet, Muhammad, fought valiantly and courageously to liberate mankind from slavery by oppressors, exploiters, nobles, slave-owners and religious scholars. They elevated human dignity from superstition, weakness and imperfection caused by shirk, fear, wild passions, egotism, arrogance and material desires. ${ }^{13}$

With the mission of liberation that the Pprophet brought, Shari'ati then declared that it is very natural if they get strong resistance from the group that had been the hegemonic class (the ruling class). There were many cases of torture received by the Prophet and his followers after they were consistent with the struggle to defend the rights they had been deprived of. Abu Jahl, as Shari'ati gave an example, a ruler of Mecca, cruelly tortured the slaves who became Muhammad's followers. Abu Jahl worried that if the slaves followed Muhammad's religion, this would trigger the emergence of a protest or even rebellion by his slaves. ${ }^{14}$

The assumption that the resistance by the Quraysh against Muhammad's struggle was due to because the aspect of liberation that he offered was reinforced by the analysis of Taha Husain, an eminent Egyptian scholar who has written it in al-Fitnah al-Kubra. Taha explains the causes of resistance by the Arabs toward Muhammad's struggle, which is none other than Muhammad's missionary factor to make Arab society more just, egalitarian and anti-oppressive.

H.A.R. Gibb, ${ }^{15}$ Islamist, strongly agrees with that opinion. He said that the resistance by the Arabs of Mecca was not due to their stubborn attitude toward the teachings of the Prophet, but because of economic and political reasons. They feared that the teachings of the Prophet could

\footnotetext{
${ }^{13}$ Ali Shari'ati, "Hajj", http://www.shariati.com//hajj.

${ }^{14}$ See Ali Shari'ati, What Is To Be Done: The Enlightened and Thinkers and Islamic Renaissance, Houston: IRIS, 1986, 106-107.

${ }^{15}$ H.A.R. Gibb, Muhammadanism, London: Oxford University, 1991, 18.
} 
threaten their economic prosperity, and especially the pure monotheistic doctrine could destroy the economic assets they controlled. In addition, they were also aware that their recognition of Muhammad's teachings could bring about a new form of political power in the oligarchic society they had formed so far.

\section{The concept of umma and imama}

In Shari'ati's view, the ideal form of society is the umma. Shari'ati does not indicate the imposition of the ideal conditions of the society with socialist, capitalist, or communist society. Umma is an ideal form of society that is very different from the existing society, such as society, nation, people, tribe, and other human community. In accordance with the root meaning, the umma was derived from the word amm meaning the way and the intention. ${ }^{16}$ On that basis and by comparison with other terms, Shari'ati concluded that "Islam does not regard blood relations, land of association or common purpose, work and means of production, race of social indicators, way of life, as a sacred ties among individuals". However, according to Shi'a, what Islam considers to be a sacred tie is a "journey" which is equally pursued by a group of people. In its definition, the umma is an expression of the notion of "a collection of persons, in which each individual agrees in the same goals and helps each other to move toward the expected goal, on the basis of the same leadership. ${ }^{17}$

The Umma is different from democracy that judges power by quantitative counting, not liberalism that advocates unfettered freedom; Not the aristocracy, not the oligarchy, nor the result of class conflict as in socialism and Marxism. The Umma consists of the sanctity of leadership - not

${ }^{16}$ Ali Shari'ati, Paradigma Kaum Tertindas, Sebuah Kajian Sosiologi Islam, Jakarta: alHuda, 2001, 107.

${ }^{17}$ Ali Shari'ati, Ummah dan Imamah: Suatu Tinjauan Sosiologis, Jakarta: Pustaka Hidayah, 1989, 34. 
the leader itself, because it will lead to fascism - a commanding and revolutionary leadership, responsible for human sacred nature according to the plan of its incident, namely as God's caliph in universe.

The term umma consists of three concepts: togetherness in direction and purpose; movement toward the direction and purpose; and the necessity of collective leadership and guidance. From this philological study, Shari'ati viewed that there could be no umma without imam ${ }^{18}$. What are the characteristics of the Imama? As the term umma states, the term imama manifests itself in the form of perfect attitude, in which one is chosen as the power of stability and mass invasion. The first means to control the masses so as to be in stability and calm, and then to protect them from threats, sickness, and danger. The latter deals with the principle of ideological, social, and ideological progress and changes, and leads their masses and thinking to an ideal form. ${ }^{19}$

Shari'ati viewed that the umma and imam are in dynamic conditions. They always move toward changes for a common goal. They consider that the ultimate and most important responsibility of the Imama is the consent of upholding the principle of government on the rules of progress, change and transformation in its quickest form, accelerating and leading people to perfection, to the disappearance of the ambitions of some individuals to tranquillity and comfort. ${ }^{20}$ In another sentence, he outlines that "the Imama in the madhhab of Shi'a's thought is a progressive and revolutionary leadership that goes against other political regimes to guide people and build society on a firm and strong foundation that will lead to awareness, growth, and independence in making decisions. ${ }^{21}$

\footnotetext{
${ }^{18}$ Ali Shari'ati, Ummah dan Imamah..., 53.

${ }^{19}$ Ali Shari'ati, Ummah dan Imamah..., 63.

${ }^{20}$ Ali Shari'ati, Ummah dan Imamah..., 64.

${ }^{21}$ Ali Syari'ati, Islam Madzab Pemikiran dan Aksi, Bandung: Mizan, 1982, 65.
} 
The Imam's job, in Shari'ati's view, is not only limited to leading men in one aspect of politics, society, and economy, nor is it limited to certain times in his position as commander, or khilafa, but his duty is to convey to mankind in all various aspects of humanity. An Imam in this sense is not limited only to his lifetime, but he is always present at all times and lives forever. ${ }^{22}$ Shari' ati reminded, however, that the Imam is not supra-human. He is an ordinary human who has many plusses over other human beings or superhuman. ${ }^{23}$

If it is so, how great and high the essence of the Imam is. Then, how is the Imam elected? Shari'ati asked, "is the Imam selected by appointment or by election, or is it based on the appointment of the Prophet or previous Imam?" Shari'ati posed an answer theoretically, it is negative for all three ..." In another paragraph, he explains that the Imam is an essential right that arises from one's self. The source is from the Imam himself, and not from external factors, such as appointment or election. "He is an Imam" continued Shari'ati, "regardless of whether he arose from the prisons of al-Mutawakkil and from the pulpit of the Prophet, whether they are supported by the whole umah or known only to his majesty by seven or eight groups of people". ${ }^{24}$ Shari'ati concludes, “... Imama is not obtained by election, but by the proof of one's ability, that is the society which is the source of sovereignty in the democratic system - not bound by the imam through government ties, but based on the bonds of the people with the reality (to the Imam). They did not appoint him as Imam, but they acknowledged his worthiness (as an Imam). ${ }^{25}$

If the above Shari'ati's logic continues, then the question is whether there is a separation of employment between Imam (recognized) and khalifa

\footnotetext{
22 Ali Shari'ati, Ummah dan Imamah..., 114.

${ }^{23}$ Ali Shari'ati, Ummah dan Imamah..., 129.

24 Ali Shari'ati, Ummah dan Imamah..., 141-143.

25 Ali Shari'ati, Ummah dan Imamah..., 145.
} 
(selected)? Shari'ati rejected this view because it would lead to a separation between religion and state. Nevertheless, it is always synonymous with imama. To them, Imama is limited to certain individuals as well as to nubuwwa, whereas government is not limited to certain times, systems and people. The only dividing line that Shari'ati affirmed was "the government (khilafa) is an infinite responsibility in history, whereas imama is limited, both in time and in person. By ignoring these differences, the imama and khilafa are actually one responsibility, to achieve a goal with one limitation, as noted above, where a ruler is not always a scholar $(\text { ulama })^{26}$

\section{Ideologizing Islam}

In Shari'ati's view, religion as an ideology is defined as "a conscious belief to answer the needs arising and solve problems in the society". Ideology is needed, according to Shari'ati, to direct a society or nation in achieving the ideals and means of struggle. Ideology is chosen to fundamentally change and reform the status quo ${ }^{27}$.

According to Shari'ati, there are two kinds of religions in the historical stage. The first is religion as an ideology and the second is religion as a collection of traditions and social conversion or also as a collective spirit of a group. The position of religion as an ideology is described by the following statement.

But one comes to understand Islam in the sense of an ideology in another way. Islam, as an ideology, is not a scientific specialization but it is the feeling has in regard to a school of thought as a belief system and not as a culture. It is about the perceiving of Islam as an idea and not as a collection of sciences. It is the understanding of Islam as a human, his-

\footnotetext{
${ }^{26}$ Ali Shari'ati, Ummah dan Imamah..., 156-159.

${ }^{27}$ See Ali Shari'ati, "Islamology", http://www.shariati.com.
} 
torical and intellectual movement, not as a storehouse of scientific and technical information. And, finally, it is the view of Islam as an ideology in the minds of an intellectual and not as ancient religious sciences in the mind of a religious scholar. ${ }^{28}$

Shari'ati explained the process of converting religion from an ideology to a social institution. The emergence of religion as an ideology, Shari'ati stated, began when the Prophets appeared in the midst of tribes and leaders of historical movements to build and awaken the society. When the Prophet proclaimed certain slogans in helping humans, the followers of the Prophet then surrounded the Prophet and declared to join the Prophet voluntarily. From this, according to Shari'ati, the religion emerged as an ideology. Later, the religion lost its original spirit and took the form of a religion as a social institution ${ }^{29}$.

From such an assumption, one can find an answer to the question of why Islam brought by Prophet Muhammad was quickly accepted by the Arab society. Islam as an ideology promoted by Muhammad brought a new social order based on the principle of justice and equality in the social structure of the society. Such a highly attractive Islamic Arab society has long been disgusted with the old aristocracy form ruled with tyranny, injustice, arbitrariness, and monopolism. The society at that time, began to find the ideological slogans as a healing medicine from the suffering and hardships resulting from the tyrannical system. Islam as an ideology is capable of giving a new belief based on the human free determination to escape from the tyrannical and social system.

Therefore, it is understandable that Shari'ati then tried to reconstruct "Shi' ite Islam" as a revolutionary ideology. Shari'ati made it clear that Islam is not a cultural Islam engendering ulama and mujtahid, nor Islam

\footnotetext{
${ }^{28}$ Ali Shari'ati, "Islamology", http://www.shariati.com.

${ }^{29}$ Ali Shari'ati, Islam Madzhab Pemikiran..., 154-155.
} 
in the general tradition, but Islam within the framework of Abu Dhar. Islam was progressively born in response to the society's problems, leading the society to achieve worthwhile goals and ideals. In this regard, Islam is understood as a comprehensive worldview and positioned as a "liberation religion" concerned with socio-political issues such as oppression, discrimination, injustice and so on. The spirit of Islam as an ideology of liberation led to the revolution of Islamic society to build a new, progressive, participatory civilization construction, without oppression and injustice.

\section{The relevance of Shari'ati's thought to social-political transformation}

The first basic problem of Indonesia as a nation is morality. Indonesia experienced a crucial moral crisis. The important political elements such as the executive, legislative and judiciary have failed to build the country. The country is like a damaged boat that loses control because its leaders are experiencing a crisis of morality. Indonesian leaders are not good examples; they are bad ones. The second problem is independence. Indonesian people experienced the euphoria of independence, the spirit of adoring independence without understanding the limits of independence itself. Thus, there are destructions of public facilities in the name of independence. The third problem is humanity. The Indonesian society experiences a humanitarian crisis that is marked by poverty and the phenomenon of expulsion of citizens from their homeland. The fourth is social justice. The problem of social justice in Indonesia is a crucial issue because there is no willingness of the political elite to achieve social justice. Social justice is only a dream that never happens. The fifth is peace amongst people, community and state. In recent years, Indonesia has experienced religious, ethnic and group conflicts. These conflicts disrupt the national stability. 
In order to to change the condition, these five basic problems of the Indonesian society should be addressed. The spirit of change matches with the discourse of revolution. The revolutionary discourse is not a radical change by violence and bloody struggles. Rather, the revolution here refers to the radicalism of the self-conscious process. It means each individual person is aware of his or her autonomy. This revolution model has two dimensions. Firstly, the individual dimension that each person performs in the process of self-existence is not only by educating himself to his art, but also his intuition of common sense to reject any irrationality. The second is the social dimension. Individual consciousness develops into social consciousness. This joint awareness continues to develop into an awareness to fight for the interests of liberation. The implementation of enlightened social consciousness will require a change of justice system (law) based on the equity of justice and welfare. ${ }^{30}$

One of Indonesia's outstanding features is diversity both physically and socio-culturally. Indonesia is a country with the highest heterogeneity on earth, based on the fact that Indonesia consists of 17,000 islands, either large or small ones, inhabited and uninhabited. Indonesia also has a large number (hundreds) of ethnic groups and regional languages. This indicates that Indonesia is very heterogeneous and dynamic in terms of social and culture dimensions. The socio-cultural heterogeneity is also supported by the religious heterogeneity, consisting of Islam, Christianity, Catholicism, Buddhism, Hinduism and Confucianism. Islam as the largest religion in Indonesia also varies in terms of the intensity of understanding and implementation from region to region.

This fact shows that the Indonesian nationhood is based on a mixture of various and diverse ethnics. If these ethnicities are applied in Europe,

\footnotetext{
${ }^{30}$ Mudji Sutrisno, "Revolusi Akal Sehat", in Masyarakat Versus Negara, Paradigma baru Membatasi Dominasi Negara, Jakarta: Kompas, 2002, 318-320.
} 
for example, each ethnic meets the criteria for becoming a nation and an independent state. The real example is the distinction between Javanese and Sundanese, it is equal to the difference between Spanish and Portuguese, two languages of two independent nations. This shows that Indonesian culture is a collection of various regional cultures. So, they must leave regionalism, ethnicism, and nativism toward cosmopolitanism. Rather, they must have an attitude of complementarity as one unity of a great nation ${ }^{31}$.

Based on this fact, the future arrangement of Indonesia must lead to national convergence, namely convergence in the field of basic social, cultural and political concepts. The meaning and purpose of national convergence are a form of mutual understanding rooted in the spirit of willingness to give and receive among individuals and tribes. The basic principle of accepting and giving is the stability of individual, ethnics, and groups to open themselves to differences and eliminate anxiety between individuals and groups. This national convergence tendency should be directed toward a more cosmopolitan outlook on life, the maturation process of every member of the nation, individuals and groups, the self-declared in selfawareness, in an ever increasing capacity, to recognize the universal values of individuals and group, to communicate with other people and groups. It means that every person or group is required not to be too attached to the exclusive symbols of individuals or the group, and their view should be developed toward more inclusivity based on the awareness of social functions and values behind the formal symbols. This cosmopolitanism spirit should be a national association, in the external and interpreted sense, which is insightful throughout all members of the nation. Based on the above matters, Indonesia has grown steadily as a nation. The most valuable assets of Indonesia are the unity of the state, the language of unity, the

${ }^{31}$ Nurcholish Madjid, Islam Kemodernan dan Keindonesiaan, Bandung: Mizan, 1995, 40. 
constitution and the philosophy of the state, and the administrative system (administration, bureaucracy) covering the whole country.

The spirit of cosmopolitanism has long been instilled by the founders of Indonesia. Soekarno, in his speech on the birth of Pancasila in BPUPKI, June 1, 1945, said very firmly that the future of Indonesia is the future of mutual cooperation based on the unity of all tribes and classes. Among the most Indonesian nation "le desir d'etre ensemble" is the Minangkabau people, which are approximately 2.5 million. The people feel themselves as a family, but Minangkabau is not a single unit, but only one small part of one unity. Yogya residents also feel "le desir d'etre ensemble", but Yogya is only one part of one unit. In West Java, Pasundan deeply feels "le desir d'etre ensemble", but Sundanese is only one small part of a single entity. In short, the Indonesian nation, natie Indonesia is not just a group of people living with "le desir d'etre ensemble" over small areas such as Mingkabau or Madura or Yogya or Sunda or Bugis, but the Indonesian nation is all human beings who according to Geopolitics that have been determined by Allah SWT to stay in unity all the islands of Indonesia from the trip of Sumatra to Papua.

This speech confirms that Indonesia is a nation that upholds the spirit of coalescence and unity, and strongly condemns all forms of tribal and group ultimates. Sukarno reminded that tribal and religious differences are not a threat but a precious treasure that must be preserved and conserved. This diversity becomes the mosaic of Indonesia's life as a guardian of world political harmony. Hence, the energy of the nation is directed to keep this harmony.

\section{Anti-ethnocentrism}

The important message of Shari'ati's thought about the umma is antiethnocentrism, that is the spirit to eliminate the blind fanaticism of tribes 
and groups. This spirit does not remove tribal and group differences but it seeks to build bridges of mutual understanding between ethnic and class on the importance of togetherness. This anti-ethnocentrism spirit is highly relevant to the Indonesia's social conditions. The land known as the emerald equator has a variety of tribes, cultures and languages. This cultural wealth, if not supported by the spirit of anti-ethnocentrism, will bear to modern fascism, that is each tribe and class will claim itself as the best tribe among the other tribes. The most fatal consequence of this tribal claim is the horizontal conflicts that will harm the harmony of life in Indonesia.

The relevance of anti-ethnocentrism to Indonesia's social change is the total eradication of ethnic fanaticism because ethnocentrism cannot answer the basic question as when one is treated unfairly because he or she is from an $\mathrm{X}$ tribe. Because one never intends to have an $\mathrm{X}$ tribe, being born there and loves the place, what ethnocentrism must do to that person is destabilizing the entire building of democracy.

The spirit of anti-ethnocentrism still recognizes the identity of each ethnic group that has objective and subjective aspects. The ethnic objective aspects are language, religion, race, regionalism and culture. The ethnic subjective aspects include five things which are subjectively interpreted by each individual. Problems will arise within the framework of subjective interpretation of ethnicity. With regard to llanguage aspect, it turns out that not all the same language users feel in one ethnic, for example among Moslem Bosnia, Croatian and Serbian. Regarding to rreligious aspect, it turns out that not all persons in one religion feel in one ethnic, for example Muslim India, Pakistan and Bangladesh. Meanwhile, in terms of the aspect of regionalism, it seems that without coming from one region, people can feel the same ethnic like the Jews. With regard to the aspect of race, it turns out that not all people having a 
typical skin colour are tied by the same race, such as coloured skin in South Africa similar to black in the United States. In terms of cultural aspect, the similarity of culture also cannot bind one ethnic because of different interpretation aspect in running culture. ${ }^{32}$

The spirit of anti-ethnocentrism in the umma is to remove the psychological burden from the objective aspect of ethnic identity to subjective interpretation, bbecause in this process of interpretation, there will be differences of sub-ethnic, religious, language, race, regional and culture. The function of the umma in the context of Indonesia is the fusion of fanaticism into a spirit of mutual understanding and mutual understanding because the harmony of Indonesia will look beautiful when each tribe exhibits cultural diversity without claiming cultural cult respectively.

\section{Universalism}

Shari'ati's explanation on the urgency of the spirit of anti-ethnocentrism should continue with the spirit of universalism. The ultimate meaning of the terminology of universalism in the umma is the recognition of the identity of each ethnic and the recognition of each ethnicity about the meaning of difference. Universalism does not intend to merge all the differences into a single truth, but the spirit of universalism is to embrace all those differences in a single bond of understanding in a harmonious society.

The relevance of the spirit of universalism to the context of being Indonesian is the emergence of a movement back to ethnicity that appears in the Indonesian political scene. This movement threatens the nation integration. The author classified this ethnocentrism movement into two ways: first, the demand for recognition of ethnic identity in the

${ }^{32}$ Mahli Zainuddin Tago, "Kegagalan Ideologi Sekuler dan Dilema Identitas Etnis (Pelajaran dari Kasus Aceh)”, Jurnal Media Inovasi No. 1 TH.X (2000), 32-48. 
form of an independent state (ethno nationalism) as voiced by Aceh, Papua and Maluku; second, the desire to maintain ethnic and religious identity between groups (horizontal conflict) such as in Ambon, Mesuji Lampung and Dayak Kalimantan ${ }^{33}$.

The phenomenon of returning to ethnicity is not a negative thing. Indonesia is not the only one in this ethnic discontent. The demands of ethnic autonomy in the world today are largely based on the reason of the lack of recognition of cultural distinctiveness and group economic survival. This global reality shows that traditional culture cannot simply be removed.

The rise of the movement to ethnicity in Indonesia is caused by the lack of recognition of ethnic culture and capitalist-oriented development that has marginalized the economies of certain ethnic members. This fact awakened the violent reaction of certain ethnic members in the form of a political movement marked by the mobilization of ethnic symbols to gain the support of community members.

The spirit of universalism is to revive the movement to ethnicity in a religious framework in the life of harmony. Each ethnic shows the distinctiveness and uniqueness to be a medium of intercultural communication within the framework of the unity of the Indonesian nation. The spirit of universalism in the context of Indonesia is the spirit of nationalism that embraces all ethnicities and cultures in the archipelago. This nationalist spirit is a political movement attempting to homogenize the cultural uniqueness, for example, to mobilize the feeling of belonging alongside other ethnic traditional songs as national. Nationalism should be implemented in a movement to preserve ethnic cultural values and make it a national treasure. Nationalism must keep a spirit of universal496.

${ }^{33}$ Rebeka Harsono, Cultural Studies, Nasionalisme dan Etnisitas, Jakarta: Kompas, 2002, 
ism that maintains a democratic process of interaction amongst ethnic populations, rather than allows the culture to dominate the majority to minority groups, moreover, the dominance of one ethnicity to another. The great task of universalism is to direct the spirit of ethnicity into a movement to absorb external values such as democracy, peace, inclusiveness, gender equality and anti-feudalism. The anti-feudalism spirit should be the main instrument because feudalism values destroy the dignity of humanity.

Universalism builds the overall values that allow each member of the ethnic community and nation state not to be stubborn to maintain group sentiment in interacting with people different from them. This awareness is expected to be the starting point of anticipating ethnic conflict.

\section{Independence}

Shari'ati emphasized the independence of individuals as a major prerequisite in the development of civilization without discrimination. This spirit of independence is a follow-up of the universalism manifested in the spirit of nationalism. The relevance of independence to social change in Indonesia is very clear, because Indonesia as a legal state must guarantee the basic rights of every individual. The efforts to preserve nationalism will flourish with the support of freedom to associate and freedom to practice their respective religions. This spirit of independence is directed at the development of cultural values of tolerance into the state's political system that can ensure each individual to be happy with their choices of life.

The spirit of universalism embodied in Indonesian nationalism must bring back independence because the society's composition will be chaotic if individuals lost their independence. Indonesia's long history proves that no concept plays such a huge role over independence. Human, personal and social relationships, in all domains of life, involve the question 
of independence, that is, how far a person can determine his own future and act as desired, without the restraints of others. In fact, freedom is the basis of happiness because only free people can truly be happy. Independence is proven to be a major productivity infrastructure, both in the areas of thought and action. An Arab proverb says that there is nothing more precious than freedom. The now fallen Berlin Wall can tell how humans are willing to sacrifice anything, if life is necessary, for the sake of independence.

Civilization and a regular society require independence as the foundation. Positive values of freedom include political rights, namely the right to vote, to hold office, to participate in political decisions, to associate with fellow citizens who share common views, and to criticize the government. Independence also needs to be limited because indefinite freedom will soon lead to anarchy. ${ }^{34}$

The significance of freedom is in line with the Latin phrase ubi societas, ibi jus (where there is society, there is law). This phrase affirms that a civilized and just society is impossible without a social and legal order. Democracy and government, on the basis of popular consent, are expressions of the positive concept of independence which is the opposite of government without the consent of the people or totalitarianism.

\section{Conclusion}

The construction of Ali Shari'ati's revolutionary Islamic thought is based on the concept of Islam as a liberative religion. The bases of liberation Islam are tauhid, umma and imama, and Islamic ideology. Islam as a liberation religion explains about war and the function of religion to liberate people from oppression and injustice. Such a religion lies upon the

\footnotetext{
${ }^{34}$ Nurcholish Madjid, Islam Doktrin dan Peradaban, Sebuah Telaah Kritis tentang Masalah Keimanan, Kemanusiaan, dan Kemodernan, Jakarta: Paramadina, 2000, 44-46.
} 
value of tauhid, which is progressive; the concept of tauhid which does not only explain about the existence of God, but also encourage the spirit to change. Where should the change be directed? The Shari'ati concepts of umma and imama provide a description of an ideal society to which the change should be aimed. It is possible when Islam is positioned not as a religion, but as an ideology of struggle.

Shari'ati's thought is highly relevant to the Indonesian socio-political transformation. Indonesia is developing, and the development should be based on the people's interest, not the interest of the elite. However, in the reformation era, Indonesia is a victim of neocolonialism and neo imperialism policies. Shari'ati's thought about umma is a solution for the problem of the nation because the thought contains the spirit of universalism, anti etnocentrism, and independence.

Shari'ati thought should be acknowledged because it can revive the spirit of Islam which is liberating. In the Indonesian context, further research is needed to implement Shari'ati thought, particularly in terms of the spirit and revolution strategy. It is because his concept of revolution was not built upon blood and violence; rather, it started from humanity and social justice. Ali Shari'sti affirmed that revolution is a way to realize humanity and universal justice.

\section{Bibliography}

Abrahamian, Ervand. Radical Islam: The Iranian Mojahedin. London: I.B. Tauris, 1989.

Azra, Azyumardi. Pergolakan Politik Islam: Dari Fundamentalisme, Modernisme, Hingga Post-Modernisme. Jakarta: Paramadina, 1996.

Brown, L. Carl. Religion and State: The Muslim Approach to Politics. New York: Columbia University Press, 2000.

Chehabi, H.E. Iranian Politics and Religious Modernism. New York: Cornell University Press, N.A.

Cosgrave, William, "The Theology of Liberation", The Furrow, Vol. 37, No. 8 (August 2007): 505-516. 
Dabashi, Hamid. Theology of Discontent: The Ideological Foundation of The Islamic Revolution in Iran. New York: New York University Press, 1993.

Gibb, H.A.R. Muhammadanism. London: Oxford University, 1991.

Harsono, Rebeka. Cultural Studies, Nasionalisme dan Etnisitas. Jakarta: Kompas, 2002.

Khomeini, Ayatullah. Islamic Government. Roma: European Islamic Cultural Centre, 1983.

Lee, Robert D., "Ali Shari'ati”, in Mencari Islam Autentik: Dari Nalar Puitis Iqbal, Hingga Nalar Kritis Arkoun. trans. Ahmad Baiquni. Bandung: Mizan, 2000.

Madjid, Nurcholish. Islam Kemodernan dan Keindonesiaan. Bandung: Mizan, 1995.

Madjid, Nurcholish. Islam Doktrin dan Peradaban, Sebuah Telaah Kritis tentang Masalah Keimanan, Kemanusiaan, dan Kemodernan. Jakarta: Paramadina, 2000.

Mortimer, Erward. Islam dan Kekuasaan. Bandung: Mizan, 1984.

Pramono, Made, "Melacak Basis Epitemologi Antonio Gramsci", in Listiyono Santoso (ed.), Epitemologi Kiri. Yogyakarta: Ar-Ruzz, 2003.

Rahnema, Ali, "Ali Shari'ati: Guru, Penceramah Pemberontak", in Ali Rahnema (ed.). Para Perintis Zaman Baru Islam. trans. Ilyas Hasan. Bandung: Mizan, 1996.

Rahnema, Ali. An Islamic Utopian: A Political Biography of Ali Syari'ati. London: I.B. Tauris and Co. Ltd, 2000.

Afrasiabi, K. L., "An Islamic Utopian: a Political Biography of Ali Syari'ati", in Middle East Journal, Vol. 54. No. 1 (Winter, 2000): 139-140.

Sachedina, Abdulaziz A., "Ali Shari'ati: Ideologue of the Iranian Revolution", in John L. Esposito (ed.). Voices of Resurgent Islam. New York, Oxford: Oxford University Press,1983.

Simon, Roger. Gagasan-Gagasan Politik Gramsci. Yogyakarta: Pustaka Pelajar dan Insist, 1999.

Sutrisno, Mudji, "Revolusi Akal Sehat", in Frans M. Parera and T. Jacob Koekerits (eds.). Masyarakat Versus Negara, Paradigma baru Membatasi Dominasi Negara. Jakarta: Kompas, 2002.

Shari'ati, Ali. On The Sociology of Islam. Berkeley, Calif: Mizan Press, 1979.

Shari'ati, Ali. Al-Insan, Al-Islam wa Madaris Al-Gharb. N.P.: Dar Al-Shahf li AlNasyr, 1979.

Shari'ati, Ali. Red Shi'ism. Houston: Free Islamic Literature, 1980. 
Shari'ati, Ali. Reflections of Humanity: Two Views of Civilization and the Plight of Man. Houston: Free Islamic Literatures, 1980.

Shari'ati, Ali. Histoire et Destinée. trans. F. Hamed dan M. Yavari-d' Hellencourt. Paris: Sindbad, 1982.

Shari'ati, Ali. Man and Islam. Tehran: University of Mashhad, 1982.

Shari'ati, Ali. What Is To Be Done: The Enlightened and Thinkers and Islamic Renaisance. Houston: IRIS, 1986.

Shari'ati, Ali. Haji. Bandung: Mizan, 1998.

Shari'ati, Ali. Abu Dzar: Suara Parau Menentang Penindasan. Bandung: Muthahhari Paperback, N.A.

Tago, Mahli Zainuddin, "Kegagalan Ideologi Sekuler dan Dilema Identitas Etnis (Pelajaran dari Kasus Aceh)", Jurnal Media Inovasi No. 1 TH.X (2000): 32-48.

Wahyudi, Yudian, "Ali Shari'ati and Bint al-Shati on Free Will: a Comparison, Journal of Islamic Studies, Vol. 9, Issue 1(1998): 35-45.

Yousef, Naghi, "Religion and Revolution in the Modern World: Ali Shari'ati's Islam and Parsian Revolution", Social and Economic Studies, Vol. 44, No. 2/3 (June/September, 1995): 37-41.

Zainuddin, A. Rahman dan Basyar, M. Hamdan (eds.). Syi'ah dan Politik di Indonesia: Sebuah Penelitian. Bandung: Mizan, 2000. 